\title{
Zmarł Champollion zwojów \\ - śp. Józef Tadeusz Milik (1922-2006)
}

Po ciężkiej chorobie w podparyskim szpitalu zmarł nieoczekiwanie 6 stycznia 2006 jeden z najwybitniejszych znawców sławnych rękopisów znad Morza Martwego Józef Tadeusz Milik. Był jednym z najwybitniejszych uczonych polskich przebywających od 1946 roku stale za granicą. Błyszczał jako epigrafik, semitolog i biblista. Znakomity znawca m.in. siedmiu języków starożytnych, w tym hebrajskiego, aramejskiego i nabatejskiego. Pracował w Centre National de Recherches Scientifiques (francuski odpowiednik Polskiej Akademii Nauk).

Józef Tadeusz Milik urodził się w Seroczynie na Podlasiu w roku 1922. Ukończył teologię w Katolickim Uniwersytecie Lubelskim w roku 1946 i został wysłany do Papieskiego Instytutu Biblijnego w Rzymie. Tam zdobył licencjat z nauk biblijnych i został odkryty jako wybitny hebraista i utalentowany epigrafik po wydrukowaniu (po włosku i łacinie) serii studiów o nowo odkrytych dokumentach znad Morza Martwego. O. Roland de Vaux, dominikanin z Francuskiej Szkoły Biblijnej i Archeologicznej w Jerozolimie, zaprosił go do swego zespołu badawczego z końcem roku 1951. Przebywał w Ecole Biblique do roku 1960.

Brał m.in. czynny udział w odkryciach groty 4 i 5 oraz w badaniach osiedla Chirbet Qumran. Spędził niemal rok na Pustyni Judzkiej i znał ją jak mało kto. Przydzielano mu do publikacji najtrudniejsze, pozabiblijne rękopisy, m.in. z groty 1, 4 i 5, z grot w Wadi Murabbaat, oraz sławny Zwój Miedziany. Opublikował pięć tomów w sławnej oksfordzkiej serii Discoveries in the Judaean desert. Był współtwórcą hipotezy o esseńskim pochodzeniu manuskryptów. Jego znakomita synteza Dziesięć lat odkryć nad Morzem Martwym ukazała się wielu językach, na kilku kontynentach. Pozostaje nadal najczęściej cytowaną monografią zwojów.

W późniejszym okresie swego życia Milik pasjonował się także dziejami mało znanego ludu Arabii Skalistej - Nabatejczyków. Opublikował w monumentalnym dziele zbiór ich starożytnych inskrypcji.

Działalność naukowa Józefa Tadeusza Milika została doceniona przez Prezydenta Rzeczypospolitej Polskiej, który w roku 1998 przyznał mu Krzyż Zasługi. Niestety nie doczekał się uznania ze strony Katolickiego Uniwersytetu Lubelskiego, mimo że w historii nauki polskiej XX wieku zapisał się

* Pełna wersja biogramu J. T. Milika mego autorstwa ukazała się w czasopiśmie „The Qumran Chronicle” 2/4 (2006), s. 77-110. 
jako najwybitniejszy semitolog i biblista zarazem. Nie tylko dziennikarze, ale i znawcy tytułowali go „najszybciej odczytującym zwój” (fastest men with a scroll), Champollionem zwojów, a nawet gigantem qumranologii. Z pewnością zasłużył na określenie „uczonego uczonych”, którym określił go w pośmiertnym wspomnieniu londynski „Times”.

Kraków

ZDZISEAW J. KAPERA 